\title{
EVROPSKÝ REGION DUNAJ-VLTAVA: NA CESTĔ K EVROPSKÉMU SESKUPENÍ PRO ÚZEMNÍ SPOLUPRÁCI
}

\section{EUROPEAN REGION DANUBE-VLTAVA: ON THE WAY TO A EUROPEAN GROUPING FOR TERRITORIAL COOPERATION}

\author{
ING. LUKÁŠ KAŇKA \\ DOC. RNDR. JIŘí JEŽEK, PH.D. \\ Katedra geografie Department of Geography \\ Fakulta ekonomická Faculty of Economics \\ Západočeská univerzita v Plzni University of West Bohemia \\ $\triangle$ Husova 11, 30614 Plzen̆, Czech Republic \\ E-mail:jezekji@kge.zcu.cz,kankal@kge.zcu.cz
}

\begin{abstract}
Anotace
Př́spěvek se zabývá iniciační a plánovaci fázi založení Evropského regionu Dunaj-Vltava, který se rozprostírá na územi třech členských států Evropské unie: České republiky, Spolkové republiky Némecko a Republiky Rakousko. Vycházi nejenom ze studia dostupných dokumentů a právních předpisů, ale také z ř́zených rozhovorù s aktéry tohoto procesu. Poukazuje na časově a finančně náročnou cestu vedoucí k jeho založení. Tento proces je predstaven na základě rěserše strategických dokumentů Evropského regionu Dunaj-Vltava, právnich předpisů Evropské unie a ostatnich dokumentů Výboru regionů Evropské unie. Př́spěvek poukazuje, že založeni takového evropského regionu je dlouhodobý a finančně náročný proces, který si vyžádal velkou míru entuziazmu zúčastněných aktérů.
\end{abstract}

\section{Klíčová slova}

evropské seskupení pro územni spolupráci, přeshraniční spolupráce, Evropský region Dunaj-Vltava

\section{Annotation}

The paper deals with the initiation and planning phase of establishing the European region DanubeVltava, which borders the territories of three member states of the European Union: the Czech Republic, the Federal Republic of Germany and the Republic of Austria. It is not only based on the study of available documents and legislation, but also on structured interviews with people involved in this process. It highlights the expensive and time-consuming path leading to the establishment of the region. This process is presented on the basis of research of strategic documents of the European Region Danube-Vltava, EU legislation and other documents of the Committee of the Regions of the European Union. This paper points out that the establishment of such a European Region is a long and costly process which requires a great degree of enthusiasm of the participating actors.

\section{Key words}

European grouping for territorial cooperation, cross-border cooperation, European region DanubeVltava

JEL classification: $R 5, O 2$ 


\section{Úvod}

V programovém období EU 2007 - 2013 byl ustanoven nový cíl politiky hospodářské a sociální soudržnosti, jenž nese název Evropská územní spolupráce; je realizován prostřednictvím programů přeshraniční, meziregionální a nadregionální spolupráce. V podmínkách ČR existuje v současné době pět programů přeshraniční spolupráce, které představují spolupráci hraničních regionů se sousedními členskými regiony z Bavorska, Saska, Polska, Slovenska a Rakouska. Tak jako cíl Evropská územní spolupráce je novinkou v současném programovém období i instrument evropského seskupení pro územní spolupráci. $V$ další části textu bude představen tento nástroj přeshraniční spolupráce na př́ikladu vytváření Evropského regionu Dunaj-Vltava.

\section{Cíl a metodika práce}

Cílem tohoto př́íspěvku je analýza př́pravné fáze založení Evropského regionu Dunaj-Vltava, který se rozprostírá na území třech členských států Evropské unie: České republiky, Spolkové republiky Německo a Rakouské republiky. Informace pro účely tohoto př́spěvku byly získány převážně z dokumentů Evropského regionu Dunaj-Vltava, Evropské komise a Výboru regionů EU, které jsou většinou dostupné na webových stránkách, a také prostřednictvím rozhovorů se zástupci regionálních samospráv z členských regionů tohoto evropského regionu.

\section{Evropské seskupení pro územní spolupráci (právní rámec)}

Evropské seskupení pro územní spolupráci (ESÚS) umožňuje vytvářet mezinárodní organizace (sdružení, společenství, svazy) s vlastní právní subjektivitou. Smyslem ESÚS je zjednodušení a podpora evropské územní spolupráce na přeshraniční, nadnárodní a meziregionální úrovni s důrazem na posilování hospodářské a sociální soudržnosti v rámci evropského prostoru (Ministerstvo pro místní rozvoj ČR, 2013). Tento relativně nový nástroj přeshraniční spolupráce je upraven nařízením Evropského parlamentu a Rady (ES) č. 1082/2006 ze dne 5. července 2006, které vymezuje rámec podle evropského práva pro vznik a fungování tohoto seskupení na úrovni Evropské unie. Toto nařízení může být dále upraveno vnitrostátními předpisy, které jsou přijaty $\mathrm{v}$ jednotlivých členských státech EU. V České republice vymezuje ESÚS zákon č. 248/2000 Sb. o podpoře regionálního rozvoje, a to konkrétně novelou č. 154/2009 Sb., která upravuje fungování ESÚS na území České republiky.

Členem evropského seskupení pro územní spolupráci se můžou stát samotné členské státy, regionální nebo místní orgány a všechny další veřejnoprávní subjekty, přičemž členové tohoto seskupení musí pocházet nejméně ze dvou členských států Evropské unie. Při zakládání ESUÚS není nutné uzavřít mezinárodní dohodu o spolupráci, která by měla být ratifikována př́slušnými parlamenty, avšak jednotlivé členské státy musí udělit souhlas účasti členů ze svých území. Povinností členů zakládajících ESÚS je uzavř́it smlouvu o spolupráci a přijmout stanovy ESÚS (EUR-Lex, 2013).

Při zakládání ESÚS je nezbytné postupovat nejen v souladu s nařízením Evropského parlamentu a Rady (ES) č. 1082/2006 o ESÚS, ale zároveň je nutné ctít právo toho státu, ve kterém se nachází sídlo ESÚS. Další podmínkou pro založení tohoto evropského seskupení je podle článku 10 nařízení o ESÚS zř́́dit alespoň tyto orgány:

- shromáždění, které tvoří zástupci členů ESÚS,

- r ředitel, který zastupuje ESÚS a jedná jeho jménem.

Přidaná hodnota ESÚS by měla spočívat $\mathrm{v}$ zefektivnění implementace přeshraničních programů spolupráce, měla by podporovat dlouhodobější projekty, u nichž je nutné zaměstnávat společný personál a spravovat společný majetek či umožnit využívat společný právní subjekt. To souvisí s vytvářením trvalých struktur, kde společná právní subjektivita může znamenat kvalitativně vyšší úroveň přeshraniční spolupráce. $Z$ tohoto pohledu je možné na základě nařízení Evropského parlamentu a Rady (ES) č. 1082/2006 o evropském seskupení pro územní spolupráci a nařízení 
Evropského parlamentu a Rady (ES) č. 1080/2006 o Evropském fondu pro regionální rozvoj určit tyto druhy využití ESÚS (Branda, 2008):

- implementace programů přeshraniční spolupráce (např vykonávání funkce řídícího orgánu nebo společného technického sekretariátu),

- realizace projektů přeshraniční spolupráce financovaných ze strukturálních fondů Evropské unie (Evropský fond pro regionální rozvoj, Evropský sociální fond) nebo Fondu soudržnosti,

- ostatní spolupráce s účastí evropského financování,

- ostatní spolupráce bez účasti evropského financování.

Na území Evropské unie se v březnu 2013 nacházelo 34 evropských seskupení pro územní spolupráci. Česká republika je v současné době členem dvou takových seskupení: European Urban Knowledge Network (EUKN) EGTC Limited se sídlem v nizozemském Haagu (člen Česká republika) a Evropské seskupení pro územní spolupráci TRITIA s o. o. se sídlem v polském městě Cieszyn (člen Moravskoslezský kraj). Dále se v současné době projednává vznik dalších 14 podobných seskupení, z nichž tři čekají na konečné schválení, šest se nachází v prrípravné fázi (České republiky se týká ESÚS - Středoevropský dopravní koridor a ESÚS Euroregion Neiße-Nisa-Nysa) a pět dalších v ideové (návrhové) fázi (European Grouping of Territorial Cooperation, 2013).

V ideové fázi se částečně nachází také Evropský region Dunaj-Vltava, který sice již splnil téměř všechny podmínky nutné pro založení ESÚS, ale jeho členské regiony se dohodli na tom, že prozatím nebudou spolupracovat prostřednictvím nově vzniklé, společné právnické osoby.

Jak ukazují zkušenosti nejenom Evropského regionu Dunaj-Vltava, ale i ostatních evropských seskupení pro územní spolupráci, tak od iniciování až po vznik společné právnické osoby vede dlouhá a finančně náročná cesta.

\section{Evropský region Dunaj-Vltava jako př́kklad Evropského seskupení pro územní spolupráci}

Evropský region Dunaj-Vltava se rozprostírá na území třech členských států Evropské unie (viz obrázek 1): Česká republika (Plzeňský kraj, Jihočeský kraj, Kraj Vysočina), Spolková republika Německo (Horní Falc, Dolní Bavorsko a okres Altötting z Horního Bavorska) a Republika Rakousko (Horní Rakousko, okresy Wald- a Mostviertel z Dolního Rakouska).

\section{Obr. 1: Územní vymezení Evropského regionu Dunaj-Vltava}

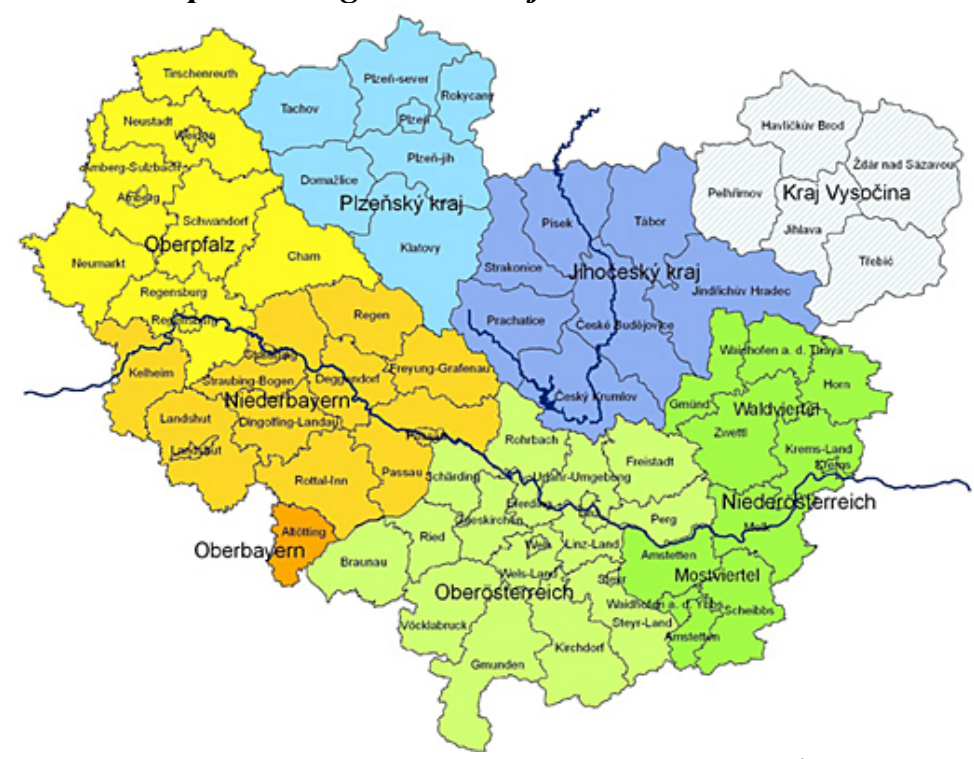

Zdroj: www.evropskyregion.cz, 2013 
V tomto regionu žije na $60000 \mathrm{~km}^{2}$ více než 6 milionů obyvatel, které symbolicky spojuje povodí řeky Dunaje a Vltavy v centrální části Evropy. Cílem tohoto evropského regionu je vytvoření základu pro intenzivní trojstrannou spolupráci v oblastech hospodářského vývoje, výzkumu, vědy, technologie a inovací, turismu, vzdělávání a dosahování kvalifikace, sociálních a zdravotních služeb, pracovního trhu, mobility a regionálního plánování. Evropský region Dunaj-Vltava byl založen dne 30. června 2012 v rakouském městě Linz jako trilaterální pracovní společenství bez vlastní právní subjektivity. Samotnému založení tohoto regionu však předcházelo více než tříleté období př́ípravných prací.

\section{Iniciace a př́pravná fáze}

Iniciativa založit evropský region, který by byl protiváhou (protipólem) metropolitních regionů Prahy, Norimberku, Mnichova a Vídně, se zrodila v lednu roku 2009, kdy se konalo první trilaterální pracovní setkání všech zúčastněných členských regionů v rakouském městě Linz. Během následujících společných jednání byl dohodnut postup př́ípravné fáze, která byla financována prostřednictvím strukturálních fondů Evropské unie. Konkrétně v rámci třech bilaterálních projektů podpořených z programů evropské územní spolupráce: Cíl 3 Česká republika - Svobodný stát Bavorsko 2007 - 2013, Cíl Evropská územní spolupráce Rakousko - Česká republika 2007 - 2013 a INTERREG Bayern - Österreich 2007 - 2013. Cílem třech uvedených paralelních projektů, realizovaných v letech 2009 - 2012, bylo provedení analýzy kooperačních sítí a analýzy potenciálů dotčeného území a př́íprava založení tohoto evropského regionu (právní analýza, výběr nejvhodnější organizační formy). Celkové náklady na realizaci uvedených projekti̊ činily přibližně 1,5 milionu EUR (přibližně 37,5 mil. Kč) a byly spolufinancovány z Evropského fondu pro regionální rozvoj (Evropský region Dunaj-Vltava, 2013b). Oficiálně byl tento třístranný projekt zahájen dne 9 . května 2009 na Den Evropy v hornorakouském Schwarzenbergu, kdy byla odsouhlasena finální struktura projektu.

\section{Analýza kooperačních sítí a analýza potenciálů}

Po schválení všech tří projektů př́íslušnými monitorovacími výbory (vrcholné orgány rozhodující o výběru projektů) jednotlivých programů přeshraniční spolupráce bylo v červenci 2009 vypsáno celoevropské výběrové řízení na zhotovitele analýzy kooperačních sítí a analýzy potenciálů řešeného území. Během druhé poloviny roku 2009 byli vybráni následující zhotovitelé: ÖAR-Regionalberatung $\mathrm{GmbH}$ z Vídně, Grontmij GmbH z Mnichova a konsorcium čtyř společností v čele s Regionální rozvojovou agenturou jižních Čech z Českých Budějovic. Analýza kooperačních sítí probíhala od června 2010 do dubna 2011. Jejím primárním cílem bylo identifikování přeshraničních kooperačních sítí na území Evropského regionu Dunaj-Vltava ve dvanácti tematických oblastech: obyvatelstvo, územní plánování a regionální rozvoj, infrastruktura a doprava, regionální ekonomický rozvoj, výzkum a vývoj, cestovní ruch, pracovní trh, sociální oblast a zdravotnictví, vzdělávání a kvalifikace, kultura, životní prostředí, ekologie a energetika a veřejná správa (veřejná politika). V rámci analýzy kooperačních sítí byly provedeny ř́zené rozhovory s klíčovými aktéry, sběry dat prostřednictvím dotazníků zaměřených na analýzu obsahu a forem spolupráce klíčových organizací. Předmětem analýzy byly také programy přeshraniční spolupráce a realizované přseshraniční projekty. V neposlední řadě bylo uspořádáno několik workshopů za účasti odborníků.

Předmětem analýzy byly především projekty přeshraniční, nadnárodní a meziregionální spolupráce, které se v daném území realizovaly v posledních deseti letech. Na tomto místě je nutné uvést, že na české straně se objevil problém, nebot' nebylo možné získat podrobné informace o evropských projektech, realizovaných před rokem 2004 (před vstupem ČR do Evropské unie). Projekty z předcházejícího období (1994 - 2003), financované z př́edvstupních programů CBC PHARE, totiž nejsou evidovány. Navíc zpracovatelé při analýze kooperačních sítí nevyužili projekty financované z dispozičních fondů (tzv. malé projekty s podporou do 25000 EUR), které podle názoru českých expertů hráli významnou úlohu při vytváření přeshraničních sítí v česko-bavorském a českorakouském pohraničí (napřs. v oblasti spolupráce základních a středních škol a dalších zařízení při 
výměnách studentů a know-how, vytváření společných turistických produkti̊ atd.). Již při projednávání této analýzy mnozí experti vyjadřovali pochybnost o její úplnosti.

$\mathrm{Na}$ analýzu kooperačních sítí navazovala analýza potenciálů, která byla dokončena v prosinci 2011. Jejím cílem byla identifikace potenciálů budoucího rozvoje tohoto evropského regionu. Problémy každé z jedenácti tematických oblastí (na rozdíl o analýzy kooperačních sítí byla z analýzy potenciálů vynechána oblast veřejné správy a veřejné politiky) byly shrnuty formou SWOT analýzy. Východiskem pro identifikaci silných a slabých stránek, př́ležitostí a hrozeb jednotlivých oblastí byla oficiální statistická data, obsahová analýza strategických dokumentů a vyhodnocení řízených rozhovorů, realizovaných $\mathrm{v}$ rámci analýzy kooperačních sítí. SWOT analýza byla široce diskutována na workshopech, jichž se zúčastnili nejenom představitelé veřejné správy z Česka, Německa a Rakouska, ale také další přizvaní experti. Předmětem kritiky byla především vypovídací schopnost srovnávacích analýz, resp. nekompatibilita dostupných statistických dat. Např. údaje o ekonomicky aktivním obyvatelstvu byly na české straně analyzovány na úrovni krajů, kdežto na německé a rakouské straně na úrovni okresů a samosprávných měst (Kreisfreie Städte).

Obr. 2: Podíl nezaměstnaných na celkovém počtu ekonomicky aktivního obyvatelstva v procentech (2008)

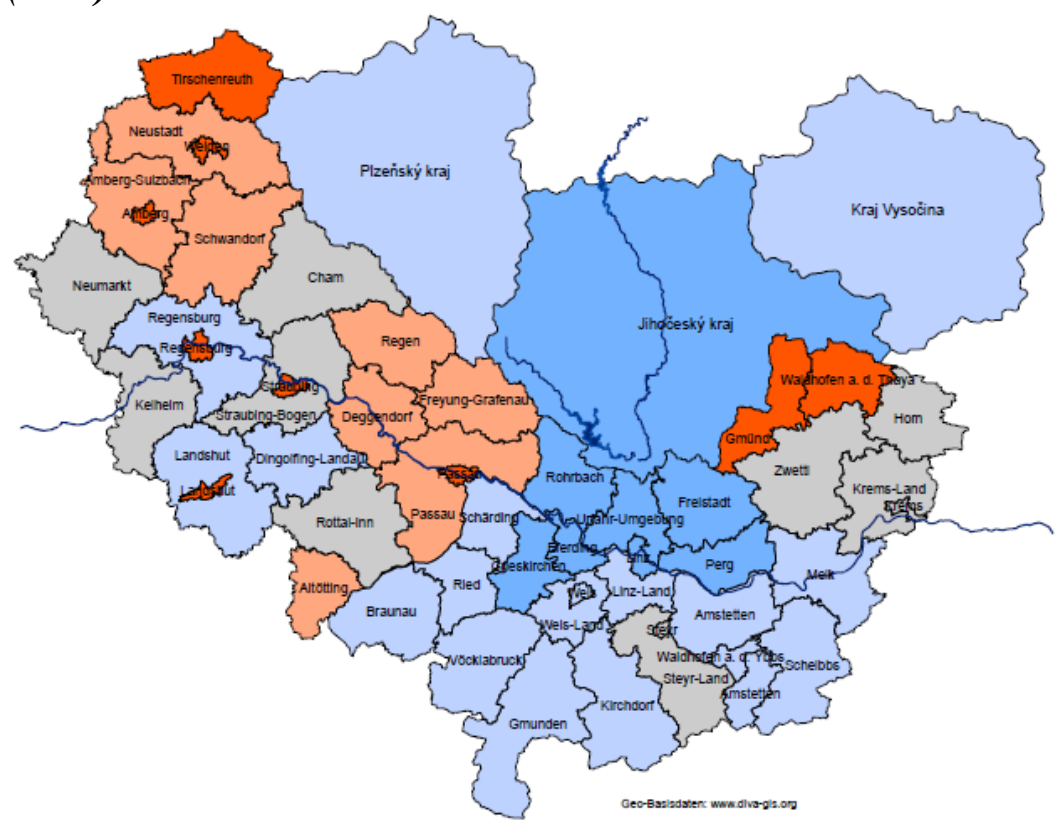

Arbeitsmarkt - Arbeitslose

Anteil der Arbeitslosen an der erwerbsfähigen Bevölkerung in \%

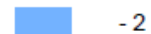

$>2-3$

$>3-4$

$>4-5$

$>5$

Wert EDM: 3,1

höchster Wert: Weiden 9,0 niedrigster Wert: Eferding 1,7

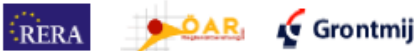

Zdroj: Jihočeský kraj, 2013

Údaje za českou stranu tak nereflektují vnitrokrajské disparity (např. v roce 2008 byla míra nezaměstnanosti v okrese Plzeň-město 3,63\% a v okrese Tachov 9,25\%). Řada připomínek k analýze potenciálů nebyla „z časového hlediska“ zapracována.

\section{Plán strategií a opatření}

Na základě (syntézou) analýzy kooperačních sítí a analýzy rozvojových potenciálů vznikl dokument s názvem „Plán strategií a opatření Evropského regionu Dunaj-Vltava“ (Evropský region DunajVltava, 2013a). Tento strategický plán byl vytvářen od prosince 2011 do března 2012. Součástí je akční plán, který identifikuje tři priority, 8 perspektiv spolupráce a 45 rozvojových aktivit:

- Inovace a růst:

o Evropský region Dunaj-Vltava jako výzkumný a inovační prostor,

o Vysokoškolský prostor Evropského regionu Dunaj-Vltava,

o Spolupráce podniků a tvorba klastrů,

o Kvalifikované pracovní síly a flexibilní trh práce.

- Udržitelnost a kvalita života: 
o Cestovní ruch zaměřený na prŕrodu, zdraví, města a kulturu,

o Obnovitelné zdroje energie a energetická efektivnost,

o Mobilita, dostupnost a doprava.

- Rozmanitost a setkávání:

o Diverzita, jazyk a interkulturní vzdělávání.

Součástí tohoto strategického plánu je také doporučené organizační uspořádání Evropského regionu Dunaj-Vltava. Navrhována je štíhlá, pružná a transparentní organizační struktura, složená ze tř́í základních prvků:

- prezídium,

- trilaterální koordinační grémium,

- společná obchodní kancelář (výkonná jednotka).

Nejvýznamnějším problémem, který vyvstal během diskusí nad návrhem strategického plánu, se ukazují odlišné kompetence zúčastněných partnerských regionů. Jestliže Plzeňský kraj má rozhodovací kompetence především v oblasti středního školství, dopravy, apod., tak vládní kraj Oberpfalz (Horní Falc) má rozhodovací kompetence hlavně v oblasti sociálních věcí, zdravotnictví, životního prostředí a kultury. Jak zdůrazňují mnozí experti zapojení do tzv. znalostní platformy, tak významným faktorem úspěšnosti je nalezení průniků kompetencí zúčastněných partnerů. Jedině tak může dojít $\mathrm{k}$ nalezení a realizaci opatření, která povedou k rozvoji daného území.

\section{Výběr vhodné právní formy}

Od ledna 2011 probíhala analýza potenciálně možných právních forem Evropského regionu DunajVltava. Tuto analýzu zpracovávala Univerzita Innsbruck ve spolupráci s Vysokou školou ekonomickou v Praze. Doporučila následující organizačně-právní formy:

- Mezinárodně-právní forma organizace (podle Madridské úmluvy),

- Evropské seskupení pro územní spolupráci,

- Spolupráce bez právně stanoveného rámce (bez právní subjektivity):

o organizační model „evropské hospodářské zájmové sdruženi“",

o organizační model „správní spolupráce na základě evropského práva“,

o organizační model „mezinárodní konference regionu Bodamského jezera“,

o organizační model „přeshraniční místní účelový svaz“ podle Úmluvy z Kalrsruhe,

o organizační model „pracovní skupina“.

Na základě podrobné organizačně-právní analýzy se představitelé zúčastněných regionů shodli, že nejlépe jejich představám odpovídá model trilaterálního pracovního společenství bez právní subjektivity. Vzorem pro vybranou právní formu byla organizace s názvem Mezinárodní konference regionu Bodamského jezera (Internationale Bodenseekonferenz). Jedná se o neformální sdružení, spočívající na politické gentlemanské dohodě zúčastněných subjektů, které má své stanovy a společnou výkonnou jednotku (sekretariát). Takto koncipovaná organizace, Evropský region DunajVltava, formálně vznikla dne 30. června 2012 v rakouském městě Linz, kde všichni političtí zástupci podepsali stanovy Evropského regionu Dunaj-Vltava.

Před konečným výběrem probíhala intenzívní diskuse o možných volbách. Problémem byla poměrně jasná představa některých regionů o optimální právní formě. Předmětem diskuse byla především otázka, zda by měl mít tento evropský region právní subjektivitu. Varianta založení evropského regionu jakožto evropského seskupení pro územní spolupráci však byla odmítnuta. Politické grémium, skládající se z regionálních politiků, se nakonec usneslo na založení pracovního společenství bez právní subjektivity. Hlavním důvodem byly relativně nízké náklady zvoleného organizačního modelu a neochota některých politiků zakládat novou instituci. Výhoda pracovního seskupení bez právní subjektivity je také jeho větší flexibilita. Slabou stránkou podle některých expertů je skutečnost, že evropský region nebude moci sám žádat o finanční podporu ze strukturálních fondů EU, nebot' nebude způsobilým žadatelem. Žadatelem budou moci být pouze právnické subjekty, které evropský region založily. 


\section{Závěr}

Příspěvek analyzuje okolnosti, které vedly ke vzniku Evropského regionu Dunaj-Vltava. Zabývá se obdobím od jeho iniciování až po formální založení (leden 2009 až červen 2012). Ukazuje, že se jednalo o dlouhodobý a finančně náročný proces. Celkové náklady přípravné fáze činily přibližně 1,5 mil. EUR. Jako nejvhodnější organizačně-právní forma bylo vybráno trilaterální pracovní společenství bez právní subjektivity. Někteří aktéři doufají, že se časem změní na „evropské seskupení pro územní spolupráci“, až si zúčastnění aktéri uvědomí výhody takové právní formy. V současné době se Evropský region Dunaj-Vltava nachází v realizační fázi a jeho hlavním předmětem činnosti je rozpracování klíčových oblastí spolupráce, za účasti odborníků z jednotlivých členských regionů.

\section{Literatura}

[1] BRANDA, P. Evropské seskupení pro územni spolupráci [online]. 2008. [cit. 2013-04-28]. Dostupné z: <http://vz.fmv.vse.cz/wp-content/uploads/6_2008.pdf>.

[2] Český statistický úrúad. Krajská správa ČSÚ v Plzni. Ökresy [online]. 2013. [cit. 2013-04-28]. Dostupné z: <http://www.czso.cz/xp/redakce.nsf/i/okresy>.

[3] EUR-Lex. 2013. Nařizení Evropského parlamentu a Rady (ES) č. 1082/2006 ze dne 5. července 2006 o evropském seskupeni pro územni spolupráci (ESÚS) [online]. [cit. 2013-04-28]. Dostupné $\mathrm{z:}$ $<$ http://eurlex.europa.eu/LexUriServ/LexUriServ.do?uri=OJ:L:2006:210:0019:01:CS:HTML>

[4] European Grouping of Territorial Cooperation. What is the EGTC [online] 2013. [cit. 2013-0427]. Dostupné z: <https://portal.cor.europa.eu/egtc/en-US/discovertheegtc/Pages/welcome.aspx>

[5] Evropský region Dunaj-Vltava (2013a). Plán strategii a opatření [online] 2013. [cit. 2013-0427]. Dostupné z: $<$ http://www.europaregion-donau-moldau.at/xbcr/SID-2829F78D2A71E5BB/Planstrategil.pdf $>$.

[6] Evropský region Dunaj-Vltava (2013b). Vznik Evropského regionu Dunaj-Vltava - informace o projektu [online] 2013. [cit. 2013-04-27]. Dostupné z: < http://www.europaregion-donaumoldau.at/xbcr/SID-E590CFDA-06080DD2/newsletter.pdf $>$.

[7] Jihočeský kraj. Analýza potenciáli̊ [online] 2013. [cit. 2013-04-29]. Dostupné z: $<$ http://www.kraj-jihocesky.cz/index.php?par[id_v] $=1644 \&$ par[lang] $=\mathrm{CS}>$.

[8] Ministerstvo pro místní rozvoj ČR. Evropské seskupeni pro územni spolupráci [online] 2013. [cit. 2013-04-29]. Dostupné z: <http://www.mmr.cz/cs/Podpora-regionu-a-cestovniruch/Regionalni-politika/Evropska-seskupeni-pro-uzemni-spolupraci>

[9] RITTER, E. H. Europäische Raumentwicklungspolitik. Inhalte, Akteure, Verfahren, Organisation. Detmond: Verlag Dorothea Rohn, 2009. 